\title{
Adél Vehrer
}

\section{Táltos, Witch, Incubus, Succubus and Other Beings in Hungarian Folklore and Mythology}

\section{Summary}

The study of Hungarian people's folk beliefs has long been a major field of research in ethnography. Studies focus on rural people's theories of the functioning of the world, mythological figures and people with supernatural powers. In folk culture this worldview and knowledge was passed from generation to generation up until the second half of the 20th century. However, hardly any of these mythological figures have survived in the public mind. This is exactly why research in this topic and a summary of the previous achievements are important, and this study will raise a few typical and important questions.

Keywords: folklore, Hungarian mythology, supernatural beings

The study of the ancient Hungarian religion has a history of a hundred and fifty years, in agreement with European peoples' efforts at rediscovering their national mythologies. A survey of the history of Hungarian mythology reveals that an ancient system of religion already existed before the adoption of Christianity. Hungarians' pre-Christian religion was not organised by any institutionalized organisation, but they believed in higher beings they worshipped, they offered sacrifices to them and sought their

Dr Adél Vehrer, Associate Professor, Széchenyi István University, Győr (vehrer. adel@sze.hu) 
help. They had shamans, who also acted as their priests. The pagan worldview survived in numerous beliefs even after the spread of Christianity, and what is more, the new religion absorbed a lot of pre-Christian elements. In the folk culture and rural world view of the period preceding the turn of the millennium, the religious explanation for the world, the old beliefs and the empirically obtained and genuine knowledge handed down for centuries co-existed. Rural people's cognition was anyway different from our current way of acquiring knowledge: they saw and experienced more in their immediate environment, and inherited far more tradition, while obtained considerably less through learning and reading. Presumably, our ancient mythology and ancient religion did not constitute a coherent system: it was fragmented linguistically, ethnically and, most of all, regionally (Bartha, 1998, p. 475).

\section{EXPLANATION FOR THE UNIVERSE}

The most important elements of cosmology could be found in folk mythology. The view of the world included beliefs regarding people's environment and everyday life. They had experiences of all visible phenomena of nature, as they lived close to nature, animals, plants and the starry sky. There are hundreds of sagas about the origin of nature and the world, and they were passed by word of mouth. The cosmological concepts primarily from legends explaining the origin of the earth and humans. The legends of Hungarian and European peasantry do not explain the world according to Christian teachings, they rather fit into a magical and religious worldview laced with ancient traditions.

\section{The Earth and the sky}

In the olden days, the Earth was held to be flat, covered by the sky as a dome firmament. It was thought to be carried by animals on their backs: a whale, a buffalo, an ox or a bear. When these animals move, there is an earthquake. If the vault of the sky opens, there is lightning. During lightning, God is said to be cracking his whip. Many think that in such a case the sky opens and Heaven becomes visible. Lightning was commonly thought to hit a place where there is a witch. Fire caused by lightning can only be put out by milk. Various explanations are given for thunder: for example, the devil is beating his wife, God's cart is rattling, or Little Jesus is angry.

The tree of life or sky-high tree depicted on various folk art objects recalls the memory of beliefs before the Hungarian Conquest. The sun and the moon frequently appear on the presentations of the tree of life (Dömötör, 1989, p. 434). The popular cult of the sun with the sun symbolism of the Catholic Church. The Sun is one of the fundamental elements of the calendar system, a time management regulator and the symbol of daylight. In the second place, it keeps off demons, who are active at night. According to folk belief data, the Virgin Mary appears in the Sun (Dömötör, 1981, p. 188). In former times, the Moon determined the system of reckoning time, and together with the Sun, it worked as a natural calendar and clock for people. Most beliefs 
related to the Moon refer to expected weather changes. The majority are empirical facts. Formerly, people thought that plants grew together with the waning and waxing moon. In accordance with this concept, they preferred to perform most agricultural works during new moon. When the Moon was waning, for example, ploughing and sowing were forbidden. Once people thought the solar and lunar eclipses were caused by some kind of a being who bit the celestial bodies, the Palóc held that a mythical beast, called markoláb, eats the Sun or the Moon. This markoláb may be a bird-lie being, a wolf or a dog (Dömötör, 1989, p. 434; Ipolyi, 1990, pp. 128-129).

The stars in the sky were particularly well-known for shepherds and wayfarers, as for centuries they found the right direction according to the patterns and positions of stars. They populated the sky with humans and animals from the Earth. In many places the constellation Orion was called "Mower", and they thought they saw him harvesting wheat. The little star Sirius next to the constellation was given the name "Lame Lass" or "Lame Kate", who carries lunch for the harvesters limping. She is lame because she stepped in a dropped scythe and cut her foot. Since then she has been unable to catch up with the harvesters. In the Lake Balaton region it was held that "a hedgehog rolled along the sky" and punched numerous holed in the sky. These holes are the stars (Dömötör, 1981, p. 190). Lots of weather forecasts are known in relation to the starry sky, and other beliefs are also related to it: comets, for instance, are thought to predict war, and a shooting star signals the release of a soul from the Purgatory (Pócs, 1990, pp. 527-536).

The rainbow was thought to end in a brook or a well and suck water from it, and so it is not advisable to stand next to such a place, as he or she may also be sucked. Anyone who could pass under the rainbow would change gender. If you finger-point at a rainbow, your finger will wither and drop off. From the colours of a rainbow, people tried to predict the harvest: red meant a lot of wine and green was seen as a sign of abundant wheat (Pócs, 1990, p. 543; Dömötör, 1981, p. 193).

\section{Mythological FiguRes}

During the past century, numerous features of beliefs related to supernatural beings were discovered as a result of research, despite the fact that Hungarian mythical figures no longer constitute a system in the way they did during the Conquest. The reason is that after the adoption of Christianity, the majority of previous figures gradually disappeared: the roles of creatures defending people and warding off harm were assumed Christian saints, or nearly all negative creatures of former beliefs were merged in the devil's figure. Actually, the witch is the only surviving creature, although the features of former creatures were also merged into the roles attributed to him or her (Pócs, 1989).

The majority of supernatural beings in Hungarian folklore were not attributed clearly positive or negative roles. Most of them were ambivalent. In addition to Hungarian folklore, there are numerous examples of ambivalent creatures in tribal peoples' mythologies. The Piaroa Indians in Venezuela still believe in such creatures. Re'yo 
(the spirit of rainforest bees) is a frequent participant in the Indian legends. A Re'yo may be evil or benign: a useful honey collecting insect, which, however, has a sting. It combines the characteristics of animal and plant demons (honey is a plant product, but it is collected by an animal). Re'yo provides shamans' important medicine, honey, as well as the raw material of masks, way (Boglár, 2001, pp. 40-42).

Mythological creatures can be divided into two groups: supernatural beings and people with supernatural powers. Creatures with supernatural powers can always be identified with a specific, living person belonging to the particular community, while supernatural beings do not appear in the form of a specific, real person.

\section{Supernatural beings}

\section{Ghost}

Ghosts, wraiths or specters are dead people who are unable to have a rest in their graves. They are the representatives of the supernatural world and have the general features of supernatural beings: changing form, invisibility, flying, sudden disappearance or emergence. In a narrower, currently used sense of the term, ghosts are the souls of dead people who have been unable to have a rest in their graves or access to the otherworld. They may appear in the external form of animals (cat, dog, swine or chicken) or a fiery beings. The time is midnight or Christmas night. Typically, they keep frightening people or lead them astray, but do not cause any harm. Formerly it was held that certain dead people remained on the Earth and haunted people for forty days after their deaths. The reason for this is that he or she committed some kind of a serious crime in his life, say a perjury or suicide by hanging. Numerous ghosts were recognized by their garment or characteristic posture (Dömötör, 1981, p. 90; Pócs, 1990, pp. 547-550).

Will-o'-the wisp, ignis fatuus, incubus, succubus, demon lover

Guardian spirits are known all over Europe. In essence such a spirit helps a certain person and makes his or her owner lucky and rich. In Hungary, the family spirit (called "chicken spook-light", ignis fatuus or "earth devil") is primarily considered as a chicken ghost that hatches out of an accidentally found egg, fulfils his master's desires but remains invisible to others. Rarely, he or she can be a person small in stature. A chicken ghost hatches out under the arm of their master, from the egg of a black hen, and fulfil all wishes of their master. The person who hatches them must live with them as if he or she was the spirit's lover. Such a spirit appears when the master's spouse is away or has died. The chicken ghost has the opposite gender of his or her master. If the master grants this wish, the chicken ghost makes him or her lucky and rich. If, nevertheless, the master wants to get rid of the spirit, he gives him or her an assignment that is impossible to fulfil, like bringing water or sand in a sifting screen. This will destroy the chicken. In many places a person who became 
rich very quickly was said to have a will-o'-the wisp. It was a widely believed that the master of a chicken ghost was a friend of the devil (Pócs, 1990, p. 563). Nowadays the Hungarian expression "pressure by an incubus", meaning an intolerable and frightening frame of mind, a nightmare, is also less used in everyday language (Dömötör, 1981, p. 79).

In the majority of the Hungarian language area, the flickering light seen in the distance over land is also called fen-fire or ghost-light. This is because rural people could not explain the various lights seen over bogs, swamps or marshes. In the olden days it was said that treasure was hidden in the ground in such places (Pócs, 1989, pp. 59-62; Pócs, 1990, pp. 566-567).

The will-o'-the-wisp is not assigned so many various roles in accurately the same combination in any other country of Europe, and academic research has not found an explanation for the reason and way these many functions have combined in the figure of the will-o'-the-wisp (Dömötör, 1981, pp. 78-79).

\section{Changeling}

It was frequently said of a child with growth retardation, who could not speak that it had been mixed up by witches. Long ago it was held that, especially before baptism, witches could easily replace the child during the night. To protect the child, a rosary was placed on the swaddling-clothes. It was thought that the witch replaced the child with her own child. To switch it back, the child is seated on a baking peel and pretend to push it into the oven. This frightens the witch, who quickly swaps the child back (Dömötör, 1981, p. 105).

\section{Devil}

In the history of beliefs, the devil is frequently negative, sometimes neutral. For example, a man in the Palóc region, who committed suicide by hanging but his life was saved, said the following about the devil: it has a tail and horse hoofs, and it was poking his eyes with a pitchfork to drop him into a lime pit, where two other devils were waiting for him. In the former Gömör county, if a lad sat on a stool made on St Lucia's day was believed to be able to see the devils dance. Such a lad could also appear in the form of a devil to scare girls. Thus, for the most part the devil is an evil and frightening figure. Children were also scared with the devil: they were told not to look into a well because there was a devil in it (Ipolyi, 1854, pp. 43-50; Dömötör, 1981, pp. 97-98).

\section{Fair lady}

The fairies and demons in Hungarian beliefs are known by several names: fair lady, white lady or fancy lady. Their name is a taboo, which means that they were considered so formidable that people did not dare to mention their name. They are young, 
long-haired ladies of alluring beauty, often dressed in white, generally roaming in groups, mainly at abandoned places, along creeks, next to bridges or in the depth of forests. They dance, sing and bathe in teams, and hold dancing parties. They seduce or kidnap men, and lead women astray or make them lose their compass. They may also take the form of a whirlwind, a wild goose or a swan. They may bring illness (paralysis or muteness) on people if they are disturbed. In such a case they may force their victim dance until he or she dies. Generally they appear at night or at noon. Their characteristic features are frequently similar to the Hungarian concept of witches. Usually only those get diseases caused by fair ladies who disturb them during dancing, procession or entertainment at the typical places and times of their appearance. For this reason it is unadvisable to pass accidentally by such places. Beliefs related to fair ladies were most widespread in Transylvania. Today, their memory is only preserved by a single place-name: the Valley of the Fairy Lady in the town Eger (Dömötör, 1981, p. 82; Ipolyi, 1854, p. 60; Pócs, 1990, pp. 557-558).

\section{Snake or snake-dragon}

Once the snake-dragon was known all over Hungarian-speaking territory. It was considered as a benevolent spirit: the whole family's welfare and prosperity depended on it. It was believed to live under the threshold or in the wall. It must not be harassed or killed, otherwise the home will be struck by bad luck: fire or death. The figure of the snake is identical to the snake-dragon or dragon. The snake often helps the learned witch-doctor, who rides it (Ipolyi, 1990, pp. 88-90; Dömötör, 1981, pp. 108-109).

\section{People Endowed with Supernatural Power}

Every member of peasant communities established contacts with supernatural beings in some or another way at some level (e.g. lust spell, healing). Some areas, however, required specialists. Healers' knowledge exceeded others' only vertically. Folk communities attributed additional knowledge to these specialists, and thought that such knowledge was from the supernatural world (Pócs, 1990, p. 579).

\section{Witch}

As a social institution, witchcraft has been traceable in every people of Europe since the Middle Ages. Witches have the most emphatic role of all mythological figures, as they incorporated numerous other beliefs. The Hungarian word for witch, boszorkány, comes from Turkic, and means a being who causes a feeling of pressure, a nightmare to the sleeping person, and in this sense he or she was considered as demonic (Pócs, 1989, p. 19). Stories clearly depict the witch as a negative figure, primarily an elderly woman, but it can also be a man. In several cases she has a physical defect, a disability or is shifty looking, but physical characteristics are not of pivotal significance. 
In the event of any personal problem or misfortune, the witch is manifest in a real, living and known person. This scapegoat role of witches was not assigned to an unchanged person, rather to the person that could be accused in the current case (Pócs, 1989, p. 9).

Witchcraft is transferred by holding hands at the witch's deathbed. She cannot die until she has not transferred her knowledge. If there is a volunteer, a broom is handed over to her.

She can put three kinds of hexes: 1) on animals or crop in the field of farming; 2) damaging human health; 3) destroying human relations.

Witches' most general harmful mischief is putting hexes on people and animals. The emphatic part of stories are about the evil eye, primarily in connection with children. For the most part, adults are abused by love spells. In such cases people turned to a knowledgeable man or a healer for help. The damage caused by witches is called witch pressure in Hungarian. At night they put their weight on a person's chest invisibly or in the form of an animal (e.g. cat).

The majority of the stories are related to cattle farming. Mischief causes the milk to dry up, loss in the profit earned on milk, or the cow to produce bloody milk. Witches often turn into cats, frogs or horses when they cast a spell on cows. They usually appear and cast spells at midnight. In order to avoid the mischief, the various form of the witch must be known. In the order of frequency, they are as follows: cat, frog, snake, horse, pig, goose and dog. A mischief is prevented by garlic: for example, on St Lucia's day, the door frame or the calf is smeared with garlic (Szendrey 1986, pp. 354-357; Pócs, 1997; Ipolyi, 1854, pp. 407-408).

\section{Wandering scholar}

The figure of the wandering scholar or wandering student was a generally known folk belief even in the 20th century. He was thought to have supernatural abilities, primarily weather magic. The wandering scholar learns his knowledge at school, he finishes thirteen or seven classes, and learns from the devil. He has a book he reads backwards to regulate cloud movement. He is wandering around in the form of a student or a beggar, in other words, as a ragamuffin. He is recognised by his tousled hair, hairy face, mane on his back and hoofs.

According to the relevant belief known all over the Carpathian Basin, the wandering scholar can generate and/or predict storm, wind and rain. They can do this in two ways: either they read storm from a book, or ride a dragon or a dragon-snake in the cloud. Wandering students cause harm if their wish is not fulfilled. In the course of their ramblings, they regularly walk into strangers' houses for milk, and if the master of the house refuses to offer him milk, he schools him with a thunderstorm. People ring church bells as a protection against the thunder created by the wandering student. The person who fulfils a wandering student's wish receives a reward, as this mythological figure can divert a hail storm approaching the village by merely reading the texts in his book (Dömötör, 1981, pp. 116-117; Pócs, 1990, p. 597). 
Adél Vehrer: Táltos, Witch, Incubus, Succubus and Other Beings in Hungarian...

\section{“Táltos"}

In Hungarian traditional folk belief, táltos is a mediator between the world of the living and that of the dead, but he may have had numerous other roles in the folk belief gradually changing over the centuries. The figure of the táltos is inherited from the shamanistic worldview, however, today he only has a positive role. Only a fragment of the characteristics attributed to the táltos at the time of the Conquest of Hungary has been preserved.

The táltos is characteristically born with an additional bone, for example an extra tooth or six fingers. However, this fact must be kept secret. In several places it was held that not long after his birth the táltos can speak, but the parents are not at liberty to reveal it. If all his unconventional characteristics are successfully kept secret, at the age of seven the ghosts come for him and torture him. At this time he falls ill, or goes hiding for three days, and gets raptured and goes into a trance. When he returns, he is able to give account of what he saw in the otherworld, where he saw the dead and was taught. The táltos has a sky-high tree and predicts the future having climbed on it. The essence of the táltos's activity is contacting the otherworld in order to fulfil assignments to the benefit of his community. According to the legends, sometimes he hides and in the form of a bull, he fights another táltos. The fight is usually over weather, accompanied by thunderstorm, wind or hail. Thus the aim of the táltos's struggle is to influence weather for the benefit of his own community (Ipolyi, 1990, pp. 14-17; Pócs, 1990, pp. 583-585; Diószegi, 1967).

\section{Necromancer}

People who keep contact with the souls of the dead and sends messages from and about them are called necromancers. They were known by various different names among peasants. They were usually named by the place of their operation, e.g. woman of Novaj or man of Csépa. Consequently, this role could be played by either women or men. There are examples of their activities to date, but in the middle of the 20th century, a large number of necromancers were operative all over the country. The majority of necromancers were Catholic women. There were several reasons for seeking a necromancer. One of them is that the dead person's soul was unable to have a rest and returned, while the other is that the correct thing was to visit the necromancer and inquire about the dead of the family at intervals regulated by tradition. The family members generally visited him shortly after the death to seek consolation.

The necromancer's task was to tell them what has made the dead person satisfied, and conveyed his or her wishes, which were proper to fulfil. He or she talked about the dead, said that he or she has hear their voices or even seen them and could bring messages from them. The necromancer did not ask for a payment, but accepted whatever was given. Another feature is that he or she can also talk about or predict deaths, lost things or animals far away in space or time. He or she can see things concealed from ordinary people, for example, he or she can find treasures hid in the ground, lost objects or disappeared persons or identify a witch (Czövek, 1987; Pócs, 1990, p. 592). 


\section{Learned people}

The term "learned man" or "scholar" is an umbrella term. In a broader sense it includes any mythological figure having supernatural capacities or additional magical knowledge as well as the aforementioned specialists of folk belief: the táltos, the necromancer, the healer and also the seer. Moreover, learned men in professions other than farming are also called by this name: the learned coachmen, learned shepherd and sometimes even midwives.

Regarding the scholar's faculties and activities, part of the data refer to general knowledge, while another part to specific skills, for example, healing, seeing treasures hidden in the ground, lost objects and persons, or fortune telling. In the narrow sense, learned persons were people living in the peasant society but engaged in professions that differed from general land cultivation and animal husbandry, or having above-average expertise and outstanding knowledge. The magical activity attributed to them is usually confined to their profession, for example, a learned hunter's knowledge to hunting, the diabolical piper's to music, and the magical activities attributed to the learned coachman are related to transport, horses and the stable.

The group of wise people include numerous persons with supernatural powers. They include positive figures, like healers or the seventh child, ambivalent ones, like the learned coachman and the learned shepherd, and negative ones, who can cast spells and put hexes on people.

\section{The learned shepherd}

The knowledge of a shepherd who can heal animals was considered as supernatural. Such a person was thought to hand down his knowledge by holding hands before his death. It was a general belief that before his death he hands down his knowledge with the help of his crook, and that the learned shepherd had a pact with the devil. One of the most widespread belief related to him is that he holds the herd together using magical methods, for example, by smoking around the herd or sticking his crook into the ground. A herd "bound" this way will remain together even in his absence.

Learned shepherds release a rabid dog or wolf on one another's herds to defend their own herds. They are able to dispel or bedevil other people's herds. Thus, due to his ambivalent supernatural power, the learned shepherd of beliefs could cause good or bad, and have a positive role in increasing the herd of his community to the detriment of the neighbouring community's herd (Pócs, 1990, p. 606).

\section{The learned coachman}

A learned coachman has power over carts, horses and roads. For instance, he can set off a horse tied up or halt a moving cart even in his absence. He uses magical objects to achieve these: an axe or a jack-knife, or tools used in his trade, a horseshoe or a 
whip. Sometimes such beliefs surrounded coachmen serving at great houses. According to various stories, they could make their carriages fly over rivers or even make dead horses pull their carriages. Their lord was unable to dismiss them, because no one else could man his horses.

As a frequent motive in legends, the carpenters working on the roof are the persons who "tie up" (halt) the horses pulling a carriage or cart that passes the house. The coachman starts to reverse the spell using some kind of an object made of iron: for example, an axe or a knife, or he simply whips up the horses. The horses start out and one of the carpenters plummets from the roof dead. The coachman is able to halt other people's horses simply with his eyes, by a whistle or using magical objects. He can release any "tied-up" (hexed) horse at any moment (he is the only person who can do this), and he can even make them dance. Competing coachmen halt each other's horses or turn the other's coach-wheels out of it place. The more knowledgeable wins (Dömötör, 1981, pp. 120-122; Pócs, 1990, p. 608).

\section{The devilish miller (the rat-catcher)}

Every smaller community or district had their own "rat-sender" (rat-catcher) miller, who performed pest control for rural households. They sent the rats either to the neighbouring village or back to the place where they came from. According to the stories of experiences, this is done in secret or alone, after he has sent everybody away from home, keeping the methods in secret.

The miller obtains his supernatural power through tests at crossroads, and uses it to entertain and amaze people while they are waiting in the mill. Irrespective of this, as a specialist of the mysterious machinery, the devilish miller was surrounded by beliefs related to his supernatural knowledge and the magical operation of the mill. This was due perhaps to the fact that most people saw modern technology for the first time in their lives in mills.

There are hearsays about hostilities between millers of watermills who had equal power and sent rats to each other by turns. Finally they died at the same time, at each other's hands. According to folk belief, the mill hand could stop the mill and after he had "tied it up", he left for work in another region. Give way to the farmer's lengthy and numerous entreaties, he finally revealed that he had to pull a wedge that did not even touch the axis (Pócs, 1990, p. 607).

\section{The learned hunter}

Legends about the learned hunter were widely known over the majority of Hungarianspeaking territories. The figure is known all over Europe, but it was the most popular in German-speaking areas. The main characteristics of this figure is that either he has supernatural helpers (ghosts and the devil), or he himself has supernatural power. He uses his knowledge in hunting: for example, his gun an shoot by itself or hares voluntarily stand in front of his gun. 
Whatever a learned hunter aims his gun at, he always hits the target, and he can shoot at any distance. If an unauthorised person uses the learned hunter's gun, he will shoot himself, or will not hit any mark at all. If he fills his gun with Sacred Host, he always hits the target. The hunter has a peculiar relationship with the games of the forest. He shoots as many hares as he wants, even all the hares across the fields. He is frequented by a miraculous hare, and he feeds it and converses with it. If he offends the hare, the latter threatens him. If he drops his handkerchief, it transforms into any animal he wants it to be. Such a game does not have a heart or a liver (Pócs, 1990, p. 609).

\section{Healers}

Healers are generally also included among learned people, as the community considered their healing capacity as supernatural. The most widespread legends related to them are about the disclosure of the disbelief of the people who visit the healer or their incapacitation by a witch or a ghost. The healer can identify the evil person remotely, in the absence of the latter.

Those engaged in healing are called witch doctors, diviners or soothsayers (javas). Folk tradition has it that they have learnt their knowledge from medical book written in the last century. However, they considered "superstitious" procedures more important than medicines. Typically women, mainly elderly ladies who treated all kinds of diseases, but some of them were specialised, for example, anointing practitioners or chiropractors. Witch doctors are rarely men. Male witch doctors were usually sought to treat specifically men's problems men did not dare to disclose to women. In the village Nagysárrét, for example, they were called "midwives for males". Their method usually included incantation.

Witch doctors did not disclose their secrets of healing to anyone: they only handed down their knowledge to selected disciples. They held a meeting once in every seven years to exchange knowledge and experiences. They flew to such meetings having turned into birds.

Thus, healers are partly herbalists with empirical knowledge, chiropractors and animal healers and partly knowledgeable people who were believed to have supernatural power. Animal healers were usually shepherds while humans were healed by midwives (Dömötör, 1981, pp. 134-141).

\section{Midwife}

Similarly to healers, midwives had a dual social role. A certain percent of the births she assisted were unsuccessful, in an extent corresponding to the given social and healthcare conditions. A midwife's duties also included care for mothers in the postnatal period, when the new-born baby was exposed to numerous dangers and the mother's milk could decrease or even run dry.

In this period people were also afraid of mischiefs by witches and the baby's replacement. The midwife was a person easily accused of the presumed hex. Conse- 
quently, beliefs regarding abusive abilities and witchcraft were inevitably related to her. The records made of witch trials frequently mention midwives. According to certain beliefs recorded in several parts of the country, midwives are pally with witches. They can bewitch and change shape. Nobody can become a midwife before she has bedevilled someone else. She can also learn her profession by killing someone. This person may be her own child or relative. Some learn witchcraft from their mothers (Dömötör, 1981, p. 126; Pócs, 1990, p. 605).

Ensorcelling and the evil eye

Anyone was thought to be capable and thus could be accused of ensorcelling or putting the evil eye on others to cause inexplicable diseases. A child who has been given the evil eye on keeps crying and cannot sleep at night. Farm animals have diarrhoea if they have been hurt by an evil eye. Children were cured with carbonized water: three pieces of charcoal were put into a pot of water one after the other. The name of a person accused of sortilege was pronounced when the charcoal was put into the water. If the charcoal sank, the person whose name was pronounced with it was considered to have bewitched the child. Then the child was washed in the carbonized water. If the identity of the person who had cast the spell was revealed, a piece of his or her hair was cut and the ill child was smoked with the burning hair. This suggests that they were not angry with the caster, as he or she has cast the spell involuntarily. The spell was usually broken with the assistance of the healer, but certain simpler forms of healing were known to every member of the rural society (Dömötör, 1981, pp. 105, 146-151).

In summary, every member of peasant communities established contacts with supernatural beings in some or another way. However, some areas of these activities required specialists. Every peasant community had their own professionals. Today we can only reconstruct the system of their operation by conclusion from the 19th and 20th century data on folk beliefs.

\section{REFERENCES}

Bartha, Elek (1998): Néphit és népi vallásosság [Folk belief and folk religion]. In: Voigt, Vilmos (ed.): A magyar folklór [Hungarian folklore]. Osiris Kiadó, Budapest, pp. 470-504.

Boglár, Lajos (2001): A kultúra arcai. Mozaikok a kulturális antropológia körébốl [Faces of culture: Mosaics from cultural anthropology]. Napvilág Kiadó, Budapest.

Czövek, Judit (1987): Halottlátók a magyar néphagyományban [Necromancers in Hungarian folk tradition]. Studia Folkloristica et Ethnographia, No. 21, Kossuth Lajos Tudományegyetem, Debrecen.

Diószegi, Vilmos (1967): A pogány magyarok hitvilága [The beliefs of pagan Hungarians]. Akadémiai Kiadó, Budapest.

Dömötör, Tekla (1998): Hitvilág [Beliefs]. In: Voigt, Vilmos (ed.): A magyar folklór [Hungarian folklore]. Osiris Kiadó, Budapest, pp. 413-442.

Dömötör, Tekla (1981): A magyar nép hiedelemvilága [Beliefs of the Hungarian people]. Corvina Kiadó, Budapest.

Ipolyi, Arnold (1854): Magyar Mythologia [Hungarian mythology]. Published by Gusztáv Heckenast, Pest (Facsimile reprint, Európa Könyvkiadó, Budapest, 1987). 


\section{Civic Review · Vol. 14, Special Issue, 2018}

Pócs, Éva (1997): Élók és holtak, látók és boszorkányok [The living and the dead, seers and witches]. Akadémiai Kiadó, Budapest.

Pócs, Éva (1989): Tündérek, démonok, boszorkányok [Fairies, demons and witches]. Akadémiai Kiadó, Budapest.

Pócs, Éva (1990): Néphit [Folk belief]. In: Dömötör, Tekla (ed.): Magyar néprajz VII [Ethnography of the Hungarians VII]. Népszokás, néphit, népi vallásosság [Folk traditions, folk beliefs and folk religion]. Akadémiai Kiadó, Budapest, pp. 527-619.

Róheim, Géza (1990): Magyar néphit és népszokások [Hungarian folk beliefs and folk traditions]. Reprint, Universum Kiadó, Szeged.

Szendrey, Ákos (1986): A magyar néphit boszorkánya [Witches in Hungarian folk beliefs]. Magvetô Kiadó, Budapest. 